\title{
Satellite observations of changes in snow-covered land surface albedo during spring in the Northern Hemisphere
}

\author{
K. Atlaskina ${ }^{1}$, F. Berninger ${ }^{2}$, and G. de Leeuw ${ }^{1,3}$ \\ ${ }^{1}$ Department of Physics, University of Helsinki, Helsinki, Finland \\ ${ }^{2}$ Department of Forest Sciences, University of Helsinki, Helsinki, Finland \\ ${ }^{3}$ Finnish Meteorological Institute, Helsinki, Finland \\ Correspondence to: K. Atlaskina (ksenia.atlaskina@helsinki.fi)
}

Received: 13 April 2015 - Published in The Cryosphere Discuss.: 7 May 2015

Revised: 9 September 2015 - Accepted: 11 September 2015 - Published: 24 September 2015

\begin{abstract}
Thirteen years of Moderate Resolution Imaging Spectroradiometer (MODIS) surface albedo data for the Northern Hemisphere during the spring months (MarchMay) were analyzed to determine temporal and spatial changes over snow-covered land surfaces. Tendencies in land surface albedo change north of $50^{\circ} \mathrm{N}$ were analyzed using data on snow cover fraction, air temperature, vegetation index and precipitation. To this end, the study domain was divided into six smaller areas, based on their geographical position and climate similarity. Strong differences were observed between these areas. As expected, snow cover fraction (SCF) has a strong influence on the albedo in the study area and can explain $56 \%$ of variation of albedo in March, $76 \%$ in April and $92 \%$ in May. Therefore the effects of other parameters were investigated only for areas with $100 \%$ SCF. The second largest driver for snow-covered land surface albedo changes is the air temperature when it exceeds a value between -15 and $-10{ }^{\circ} \mathrm{C}$, depending on the region. At monthly mean air temperatures below this value no albedo changes are observed. The Enhanced Vegetation Index (EVI) and precipitation amount and frequency were independently examined as possible candidates to explain observed changes in albedo for areas with $100 \%$ SCF. Amount and frequency of precipitation were identified to influence the albedo over some areas in Eurasia and North America, but no clear effects were observed in other areas. EVI is positively correlated with albedo in Chukotka Peninsula and negatively in eastern Siberia. For other regions the spatial variability of the correlation fields is too high to reach any conclusions.
\end{abstract}

\section{Introduction}

Broadband surface albedo, defined as the fraction of the solar energy (short-wave radiation in spectral range from 0.3 to $5 \mu \mathrm{m}$ ) reaching the Earth surface and reflected upward, plays an important role in the Earth energy balance (IPCC, 2013). It determines the amount of radiation absorbed by the surface and, consequently, the energy available for heating of the surface and the atmosphere. Albedo varies with surface type, vegetation density and growth conditions, moisture, etc. The short-wave (SW) snow albedo varies from 0.9 to 0.95 for fresh snow (Wuttke et al., 2006) and decreases gradually to values down to $0.5-0.6$ for aged snow. The albedo of snowfree surfaces is much lower, for instance $0.08-0.3$ for soil, depending on soil type and wetness (Idso et al., 1975; Matthias et al., 1999), 0.17-0.28 for grassland (Song, 1999), or 0.080.13 for boreal forest (Baldocchi et al., 2000; Lukeš et al., 2014). The greatest interannual variability occurs at high latitudes in the Northern Hemisphere (NH) due to seasonal variations in snow cover, which is further augmented by snow age and other snow properties, and deposition of absorbing material. The snow cover extent in the $\mathrm{NH}$ has been observed to decrease during the past decades (Brown and Robinson, 2011), in particular in the spring season. Observations by Peng et al. (2013) at 400 stations in the NH show that the snow cover duration decreased between 1979 and 2006. At 216 of these stations the number of snow cover days decreased on average by as many as 5 days decade ${ }^{-1}$. Earlier snowmelt was detected at 210 Eurasian stations; 84 of them experienced a shift in snowmelt of 5 days decade ${ }^{-1}$ (Peng et al., 2013). 
Loss of snow-covered areas is related to the increase in air temperature. Brown and Robinson (2011) estimated that for each $1^{\circ} \mathrm{C}$ of warming in the $\mathrm{NH}\left(40-60^{\circ} \mathrm{N}\right)$ the loss of snow is 1.44 million $\mathrm{km}^{2}$ in March and 2.00 million $\mathrm{km}^{2}$ in April. Air temperatures at northern latitudes increased several times faster than that in the tropics (Screen, 2014) and affected the snow cover extent in the NH. The change in air temperature can explain $50 \%$ of the variability in the NH spring snow cover extent during the years 1922-2010 (Brown and Robinson, 2011). Decrease in snow mass leads in turn to an increase of absorption of solar radiation by darker snow-free surfaces, causing a faster increase in temperature, thus triggering a positive feedback: larger absorption of radiation enhances further warming. This feedback is usually referred to as snow-albedo feedback (SAF). The influence of snow cover on the radiative balance is the strongest during the spring months, and warming observed in the 20th century was most likely enhanced by the retreat of snow cover (Groisman et al., 1994).

Air temperature can affect snow properties, which in turn change snow albedo (Wiscombe and Warren, 1980; Taillandier et al, 2007). At higher temperatures snow grains are larger as the air temperature is higher (e.g., Marbouty, 1980; Flanner and Zender, 2006) which results in a decrease of the single scattering albedo (SSA). In the larger snow grains the chances of a photon to be absorbed are greater due to the increased optical path within an ice crystal (Warren, 1982). A decrease in the SSA is the primary reason for the decrease of snow albedo for wavelengths shorter than $2.5 \mu \mathrm{m}$ (Wiscombe and Warren, 1980; Nakamura et al., 2001). Grain size is the main physical factor responsible for snow-albedo variations (Domine et al., 2006). The snow grain growth process contributes to the positive snow-albedo feedback loop, increasing the absorption of radiation by the snow in the surface layer. It results in the increase of snowmelt and thus in a decrease of the surface albedo which consequently results in stronger absorption of solar radiation. These processes clearly affect the Arctic climate and augment the effect of temperature changes at high latitudes.

An experimental study by Aoki et al. (2003) shows that snow albedo is very stable at temperatures below $-10^{\circ} \mathrm{C}$ and decreases when the surface temperature increases to above $-5^{\circ} \mathrm{C}$. Based on measurements at four Russian stations, Roesch et al. (1999) found that the snow albedo could be parameterized in terms of a polynomial function of the surface temperature for temperatures between -10 and $0{ }^{\circ} \mathrm{C}$, while at lower temperatures the albedo is independent of temperature. A number of climate models parameterize the snow albedo as a function of the surface temperature, where snow albedo varies at temperatures below zero and, for instance, $-1{ }^{\circ} \mathrm{C}$ (Collins et al., 2004), $-2{ }^{\circ} \mathrm{C}$ (Best et al., 2011) and $-5^{\circ} \mathrm{C}$ (Roeckner et al., 2003).

In addition to air temperature, other factors may affect snow albedo, such as the amount and frequency of precipitation, changes in vegetation or darkening of the snow sur- face by deposition of absorbing material such as absorbing aerosol particles. Climate models predict a decrease of the spring snowfall during the 21 st century over most of the North American territory and Europe, and an increase in the Siberian and Canadian tundra, in the Arctic Archipelago and in Greenland (Krasting et al., 2013). However, winter snowfall is projected to increase over much of Siberia and the northern part of North America, potentially increasing the snow-covered area in the NH. Changes in the amount and frequency of precipitation can alter the snow properties and, therefore, the surface albedo: fresh snow has a higher albedo than aged snow with larger grain size (e.g., Nakamura et al., 2001). As snow ages, it has a longer exposure to deposition of impurities, such as dark aerosol particles or vegetation litter, which reduces the albedo (Melloh et al., 2001; Hansen and Nazarenko, 2004; Aoki et al., 2006; Winkler et al., 2010). The net effect of precipitation on the surface albedo will be a combination of the above-mentioned processes, ultimately determined by the air temperature - its mean, magnitude and sign of trends (Knowles et al., 2006).

Vegetation productivity in the subarctic region has increased recently (Barichivich et al., 2013) and is associated with the rise in summer warmth, which is connected to sea ice retreat (Dutrieux et al., 2012). Vegetation is darker than snow and, hence, the presence of vegetation results in a decrease of the albedo of snow-covered areas. In the presence of snow, forested areas have a very low albedo in comparison with open ground, typically in the range of $0.1-0.2$, with sometimes higher values up to about 0.3 , when snow is present on the top of the canopy (Betts and Ball, 1997). The influence of boreal forests on temperature in a changing climate is not well understood: the effect of low forest albedo may exceed the effect of increased carbon uptake, and forests may warm the climate (Bonan, 2008). Chapin III et al. (2005) have shown that shrub expansion in the tundra (Naito and Cairns, 2011) is likely to increase substantially and might play a great role in tundra warming. Sturm et al. (2005) found that if tall shrubs protrude above the snow and cover $10 \%$ of the surface, the albedo decreases by $30 \%$. These authors also report that the transition from shrub-free tundra to shrubland can increase the absorbed radiation during periods of snow by $69-75 \%$, depending on the latitude.

Surface albedo is a key parameter in climate models and has to be accurately parameterized. It is not possible to correctly simulate SAF without knowing how the surface albedo at high latitudes is modified by the processes described above. Currently, the land surface albedo in climate models is parameterized in terms of land cover or vegetation types, surface parameters (e.g., snow cover fraction and extent), and atmospheric conditions simulated in the model. Prescribed ground and canopy albedo during snow-covered periods, together with varying vegetation masking, might be responsible for the large spread in the estimates of SAF in CMIP5 models (Qu and Hall, 2014). Wang et al. (2006) concluded that uncertainties in snow cover properties are among the key 
error sources in surface albedo simulations; they dominate model performance despite the high complexity of the land model parameterizations.

Ground-based observations of albedo properties at high latitudes are very sparse. As an alternative, satellite remote sensing can be used to monitor albedo changes over vast areas. The frequency of such observations depends on the swath width of the instrument and the orbit. The footprint of satellite observations is much larger (hundreds of meters at nadir) than that of surface-based or tower measurements. Furthermore, satellite data are often integrated over many pixels, extending the resolution to several $\mathrm{km}$. Hence, satellite measurements do not provide as much detail on spatial and temporal variations as ground-based measurements. Where in situ measurements might fail to represent regional estimates (Davidson and Wang, 2004), satellite data may be more representative. They may therefore be useful as a source of validation data for land parameterization schemes in climate models, which usually have an even coarser spatial resolution (e.g., Bender et al., 2006; Alton, 2009; Hagemann et al., 2013; He et al., 2014).

In this contribution we present the results from a study on the use of satellite data to obtain information on the snowcovered surface albedo. The goal of the study is to identify systematic changes in the surface albedo during the transition spring period (March, April and May), and to determine the effect of factors such as (1) snow cover fraction (SCF), (2) air temperature, (3) precipitation amount and frequency and (4) vegetation greenness. The area of interest is north of $50^{\circ} \mathrm{N}\left(\mathrm{NH}_{50}\right)$ and covers all land territories except Greenland and Iceland. Our study focused only on the territories where at least once during the study period land was covered by snow with $\mathrm{SCF}>1 \%$. We use surface albedo data which have routinely been provided by the Moderate Resolution Imaging Spectroradiometer (MODIS) since the year 2000. This data set is not yet sufficiently long to be appropriately utilized to provide climatologically significant results. Nonetheless, it is a consistently validated product readily available for different research purposes (Schaaf et al., 2011), and we aim to describe observed changes as they are seen and give an explanation where possible.

\section{Data}

\subsection{MODIS data}

\subsubsection{Albedo}

The MODIS Bidirectional Reflectance Distribution Function (BRDF) and Albedo algorithm utilizes multiple spectral bands to retrieve broadband albedo information. The algorithm uses a semi-empirical kernel-driven bidirectional reflectance model to describe the anisotropy of land surface reflectance (for details see Lucht et al., 2000; Schaaf et al.,
2002). BRDF specifies the angular distribution of the reflection of a target as a function of illumination and viewing geometries, and it is wavelength-specific. Cloud-free, snowflagged and atmospherically corrected surface reflectances at seven MODIS bands (1-7, centered at 648, 858, 470, 555, 1240,1640 and $2130 \mathrm{~nm}$ consecutively), accumulated during a cycle of 16 days, are used to retrieve BRDF parameters. BRDF functions are angularly integrated and converted to three broadband albedos $(0.3-0.7,0.7-5.0$ and $0.3-5.0 \mu \mathrm{m})$. If fewer than seven observations were collected during a 16day period, or the collected observations do not fit the BRDF model well, a backup magnitude inversion algorithm is applied. The albedo retrieved with the magnitude inverse algorithm is assigned a lower-quality flag, but the difference in quality between data from the mainstream and backup algorithms is minor (Salomon et al., 2006). If the number of available observations is less than three, a fill value from an a priori BRDF database is assigned to a given pixel. Retrieval is conducted every 8 days and is based on the observations accumulated during 16 days (collection V005). This data processing overlapping increases the frequency of obtaining high-quality data, but can lead to an autocorrelation in retrievals if an observation is used in more than one 16day processing period (Schaaf et al., 2011). If the majority of the days in each of the 16-day periods were snow-covered, only these observations are used in the retrieval. But if only few observations indicate the presence of snow, these days are discarded from processing, and the albedo is computed as if the surface were snow-free (Schaaf et al., 2002). This may cause bias in estimating the surface albedo during the snowmelt period, when the transition from snow-covered to snow-free conditions may greatly affect albedo values.

The MODIS MCD43C 3 product (collection V005) provides information on the directional hemispherical reflectance (black-sky albedo) and the bihemispherical reflectance (white-sky albedo). In this study we used the shortwave broadband $(0.3-5.0 \mu \mathrm{m})$ black-sky albedo, which is defined as the reflection of direct radiation in the absence of a diffuse component of illumination. MCD43C3 (NASA, 2006a) is a combined product from two MODIS sensors onboard the Terra and Aqua satellites with a spatial resolution of $0.05^{\circ}(5600 \mathrm{~m})$ in a latitude/longitude Climate Modeling Grid (CMG).

The albedo product has been extensively validated (e.g., Stroeve et al., 2005; Salomon et al., 2006; Liu et al., 2009; Wang et al., 2014) and the algorithm has been proven to be stable and reliable, and the product is suitable for climatological studies. The uncertainty of the highestquality data is reported to be well less than $5 \%$ as compared to field measurements, and less than $10 \%$ for data of lower quality (http://landval.gsfc.nasa.gov/ProductStatus. php?ProductID=MOD43). 


\subsubsection{SCF}

MODIS MCD43C3 also provides data on SCF. The MODIS snow mapping algorithm is based on the Normalized Difference Snow Index (NDSI), which utilizes the fact that snow has a high reflectance in the visible part of the solar spectrum and low reflectance in the infrared (Hall et al., 2002). MODIS channels $4(0.55 \mu \mathrm{m})$ and $6(1.6 \mu \mathrm{m})$ for Terra or channel $7(2.1 \mu \mathrm{m})$ for Aqua are used to calculate NDSI as follows:

$\mathrm{NDSI}=\frac{\mathrm{Ch}_{4}-\mathrm{Ch}_{6 / 7}}{\mathrm{Ch}_{4}+\mathrm{Ch}_{6 / 7}}$

where $\mathrm{Ch}_{4}$ and $\mathrm{Ch}_{6 / 7}$ are reflectances in MODIS channels 4 , and 6 or 7 , respectively.

Non-densely vegetated pixels with NDSI $\geq 0.4$ and a reflectance in channel $2(0.841-0.876 \mu \mathrm{m})$ of larger than $11 \%$ are mapped as snow-covered. The $11 \%$ threshold screens out liquid water pixels that may have high NDSI values. In forested areas, the NDVI (Normalized Differential Vegetation Index) is used together with the NDSI to map snow cover (Klein et al., 1998). NDSI is able to separate snow-covered pixels from those which are cloud-contaminated and those which are snow-free.

The determination of SCF in each $0.05^{\circ} \mathrm{CMG}$ cell is based on the fraction of the number of snow-covered MODIS pixels (resolution $500 \mathrm{~m}$ ) to the total number of MODIS pixels within each $0.05^{\circ}$ larger pixel. The quality of the SCF within a MODIS $500 \mathrm{~m}$ pixel has been studied by Salomonson and Appel (2004) who report that the mean absolute error is less than 0.1. The validation study by Hall and Riggs (2007) shows that the overall accuracy of the MODIS snow maps is $93 \%$, with lower accuracy over forests, complex terrains and ephemeral snow areas.

\subsubsection{EVI}

The vegetation index (VI) is a measure of canopy greenness. It reflects properties of the canopy, its structure, leaf area and chlorophyll content, and can be used as a proxy to fractional vegetation cover (Ormsby et al., 1987; Carlson and Ripley, 1997). The EVI (Enhanced Vegetation Index) is one of the two routinely produced vegetation indices from the MODIS sensors (Huete et al., 2011). In this study we chose EVI over the more widely used NDVI (Normalized Difference Vegetation Index) because it is less sensitive to soil and atmospheric effects. Moreover, its signal does not saturate as fast as that of NDVI (Huete et al., 2002). The EVI is computed as follows:

$\mathrm{EVI}=2.5 \frac{\rho_{\mathrm{N}}-\rho_{\mathrm{R}}}{\rho_{\mathrm{N}}-C_{1} \rho_{\mathrm{R}}-C_{2} \rho_{\mathrm{B}}+L}$,

where $\rho_{\mathrm{N}, \mathrm{R}, \mathrm{B}}$ are reflectances in the near infrared, red and blue bands; $L$ is a soil adjustment factor; $C_{1}$ and $C_{2}$ are aerosol resistance correction factors (Huete et al., 1999). Coefficients currently used in the algorithm are, $L=1, C_{1}=6$ and $C_{2}=7.5$.
In this study we used the MOD13C2 (V005) data set provided as a monthly product on a $0.05^{\circ}(5600 \mathrm{~m})$ resolution grid. MOD13C2 (NASA, 2006b) comprises composites of the 16-day and $1 \mathrm{~km}$ resolution MOD13A2 standard product. In our analysis we chose to use data for June because in this month the effect of snow cover on the EVI values is minimal. The presence of snow decreases EVI values due high snow reflectance at wavelengths in the visible and low reflectance in the NIR (near-infrared) band (Huete et al., 2002; Zhang et al., 2006). Furthermore we assumed that an increase in the maximum EVI might be associated with an increase in non-green biomass that might protrude above the snow and decrease the albedo with time.

\subsection{CRU climate data set}

The Climatic Research Unit (CRU) TS3.21 data set (Jones and Harris, 2013) provides homogenized monthly climate data interpolated from over 4000 weather stations spread around the world gridded to a spatial resolution of $0.5^{\circ}$ (Mitchell and Jones, 2005). Among the available parameters are cloud cover, diurnal temperature range, frost day frequency, precipitation, daily mean temperature, monthly average daily maximum temperature, vapor pressure, potential evapotranspiration and wet day frequency. In this study we used monthly means of daily mean temperature, precipitation and wet day frequency.

\section{Methods}

All data were reprojected and resampled to the $25 \mathrm{~km}$ EASEGrid (Equal-Area Scalable Earth Grid), which is widely used in the analysis and visualization of data for the polar areas (Brodzik and Knowles, 2002). MODIS $0.05^{\circ}$ resolution data sets were first reprojected to the EASE $5 \mathrm{~km}$ grid with the nearest neighbor method in such a way that each $25 \mathrm{~km}$ grid would contain $5 \times 5$ smaller grids. In a second step, data were aggregated to the $25 \mathrm{~km}$ EASE grid, where mean values were stored. Additionally, monthly means for surface albedo and SCF were calculated to match the temporal resolutions of the EVI and CRU climate data. CRU time series were reprojected and resampled to the EASE $25 \mathrm{~km}$ grid with a bilinear interpolation method. All data pixels for any given month and year with corresponding SCF less than $1 \%$ in each of the $25 \mathrm{~km} \times 25 \mathrm{~km}$ grid cells were discarded from the analysis. This masking out was done separately for each month and year.

We chose Spearman's rank correlation over linear Pearson correlation in our calculations, because the response of surface albedo to changes in the studied variables might not be linear.

Due to the coarse temporal resolution of the data, it was problematic to construct maps of correlation coefficients: each pixel would have a maximum of 13 values to calculate 
correlations (years 2000-2012). Assuming that the studied parameters are spatially autocorrelated, we applied a running window of $3 \times 3$ pixels, thus increasing the amount of data by up to 9 times (less on the edges of data matrices).

To study connections between the albedo and air temperature, precipitation or vegetation under full snow cover conditions, we eliminated all pixels where snow cover was not complete $(\mathrm{SCF}<100 \%)$ at any time during the study period. In other words, if for any given month a pixel was assigned $\mathrm{SCF}<100 \%$ at either of the years during the study period, it was discarded from this part of the analysis for the given month. For instance, if in April of the year 2001 the mean SCF of a pixel was $<100 \%$, this pixel was masked out for all studied years in April. This selection reduced the amount of data available for the analysis, but ensures that a strong effect of SCF variations on albedo is excluded, and that the main part of the analysis is conducted over territories fully covered with snow. The size of the $100 \% \mathrm{SCF}$ area decreases from month to month as spring proceeds and more areas experience snowmelt. In particular, in May this area includes only Taymyr and subarctic Canada with the Arctic Archipelago, while more southern territories are cut out. Applying identical masks would drastically narrow the study area, or, alternatively, May would need to be left out of the analysis. Therefore, different masks for March, April and May were used to maximize the study area and data availability. Considering that all pixels with incomplete snow cover were masked out, the mask for any given month was the same for all years considered. Furthermore, the study domain was divided into several smaller areas, based on their geographical position and climate similarity (Fig. 1). The division was done as follows.

- The Russian Far East and Siberia (in this article referred to as Siberia) region can be described as an area with subarctic and arctic climate, with different levels of continentality. During long cold winters, arctic air masses dominate. Climate severity increases from west to east and with distance from the Bering Sea.

- The Taymyr Peninsula is considered in this work separately due to the fact that no SCF changes occurred throughout all spring seasons for 13 years in a large part of the region. Taymyr belongs to the arctic climate belt with mean winter temperatures of -25 to $-35^{\circ} \mathrm{C}$ and annual precipitation of $250-300 \mathrm{~mm}$, mainly occurring in the form of snow. It is a tundra region.

- Most of Fennoscandia, which includes Scandinavia, Finland and Kola Peninsula (referred to as Scandinavia in this work), has severe long winters in its northern part. Snow cover lasts for a long time, and the growing season is short. The southern part is largely affected by its closeness to the Atlantic Ocean and is characterized by milder winters with little snow. Vegetation changes
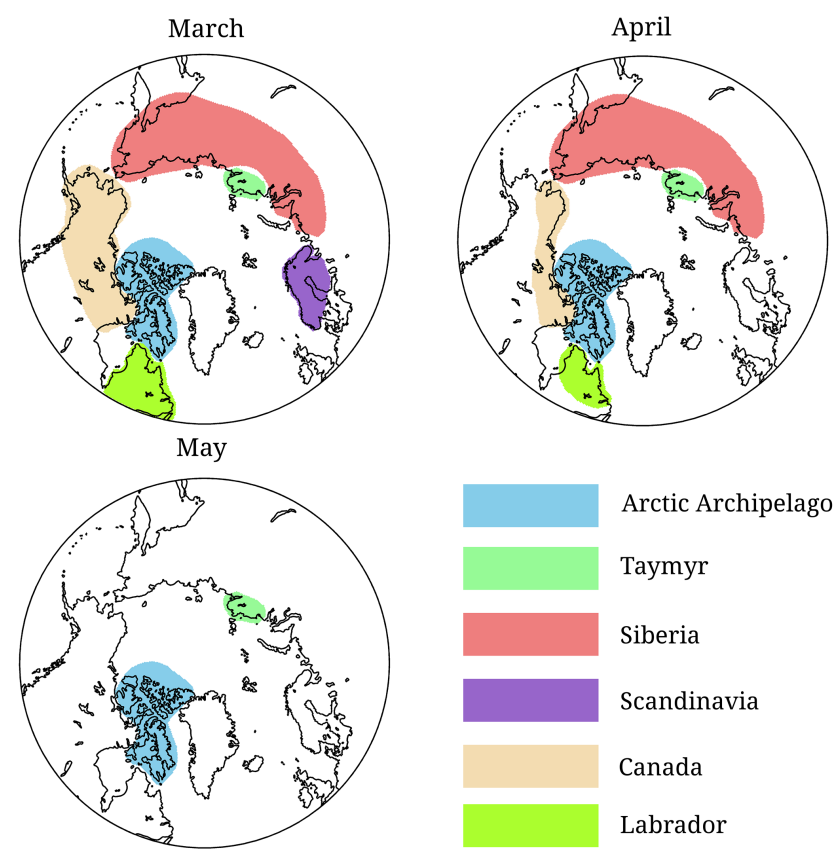

Figure 1. Different regions considered in the study and their extent for $100 \%$ SCF in the 3 months of interest: March, April and May.

from tundra in the north to the coniferous and mixed forests in the south.

- The northern Canada and Alaska area lies in the arctic and subarctic climate belts. Winters are long and cold. Most of the precipitation comes in the form of rain during the summer period. Snow cover can last almost all year around. Land cover in this area is tundra in the north, and shrubs and forest in the south.

- The Labrador Peninsula climate can be categorized as humid continental due to the closeness to the sea. Winters are mild with a lot of snowfall. Northern Labrador belongs to the tundra biome, while its southern part is covered with taiga forest.

- The Canadian Arctic Archipelago has a typical arctic climate with long, cold winters and very short, cool summers. Vegetation consists of dwarf shrubs, grasses, mosses and lichens.

The actual masks applied in the calculations deviate from those depicted in Fig. 1, depending on the data gaps in data sets and the $\mathrm{SCF}<100 \%$ filter.

\section{Results}

\subsection{Albedo and SCF changes}

Changes in SCF and albedo in the $\mathrm{NH}_{50}$ during the period 2000-2012 for each of the spring months are presented in 
Fig. 2. The changes have been calculated as a linear regression in a scatter plot of the parameter of interest in a certain month versus the years. Blue colors indicate an average increase over these years, red indicates a decrease, with the actual values indicated in the color bars at the bottom of Fig. 2. In March, the snow cover changes (trend different from zero) influenced $58 \%$ of all snow-covered areas, while in April these changes affected $74 \%$ and in May, $91 \%$.

The March SCF decreased in most of the central East European Plain, the south of the West Siberian Plain, and on the Central Siberian Plateau. In Canada the March SCF decreased in the Ontario province and in northern Alberta. In contrast, SCF increase is also observed in certain areas, such as around the Baltic Sea, in parts of eastern Europe and Russia, the southern part of the West Siberian Plain and the Transbaikal area. The largest increases are up to $+30 \%$. In North America, increases occur in the northern Great Plains in Alberta and in the Saskatchewan provinces. At other territories changes are less than $1 \%$.

In April, areas with a negative SCF trend were larger, and cover a large part of the Eurasian territory from central Scandinavia to the Far East of Russia, and in North America from central Alaska to southern Quebec along the Laurentian Upland. On the other hand, the territories in Europe where SCF increases are smaller in April than in March. They cover Estonia and adjacent territories in western Russia. In the North American sector, however, the areas with increased SCF were slightly larger, such as east of the Rocky Mountains, and part of Alaska and the Yukon Plateau.

In May, almost all snow-covered areas are affected by SCF changes. In the North American domain, the SCF mainly decreased with a small exception of positive trends on the Ungava Peninsula, the central Labrador Peninsula, the western shore of the Hudson Bay and western Alaska. Despite the fact that SCF increased in March and April in the Great Plains, it did not affect SCF in May: there the snow is already completely melted by this time. In the Eurasian sector, a small part of land, which includes the Northern Urals and part of the Khabarovsk region of the Russian Far East, experiences an increase in SCF with a maximum of up to $30 \%$. The Taymyr Peninsula and the Yano-Indigirka lowland are the only areas in Eurasia where land remained fully snowcovered.

In the areas where the SCF changed, the albedo exhibits similar spatial patterns. The sign and magnitude of changes in both variables coincide; maximum albedo changes are $\pm 0.312 \mathrm{yr}^{-1}$. Correlation coefficients for SCF and albedo are positive and have high values $(R>0.7)$ over most of the study domain, excluding some scattered pixels (Fig. 3). The correlation was found to be significant (not shown) with $p$ values $<0.05$ for all pixels with moderate $(R=0.5-0.7)$ and strong correlation $(R>0.7)$. Averaged over the whole study area, SCF and albedo also correlate strongly. In Fig. 4a, time series of the mean SCF and the mean albedo in $\mathrm{NH}_{50}$ for each of the spring months are shown. The variations in
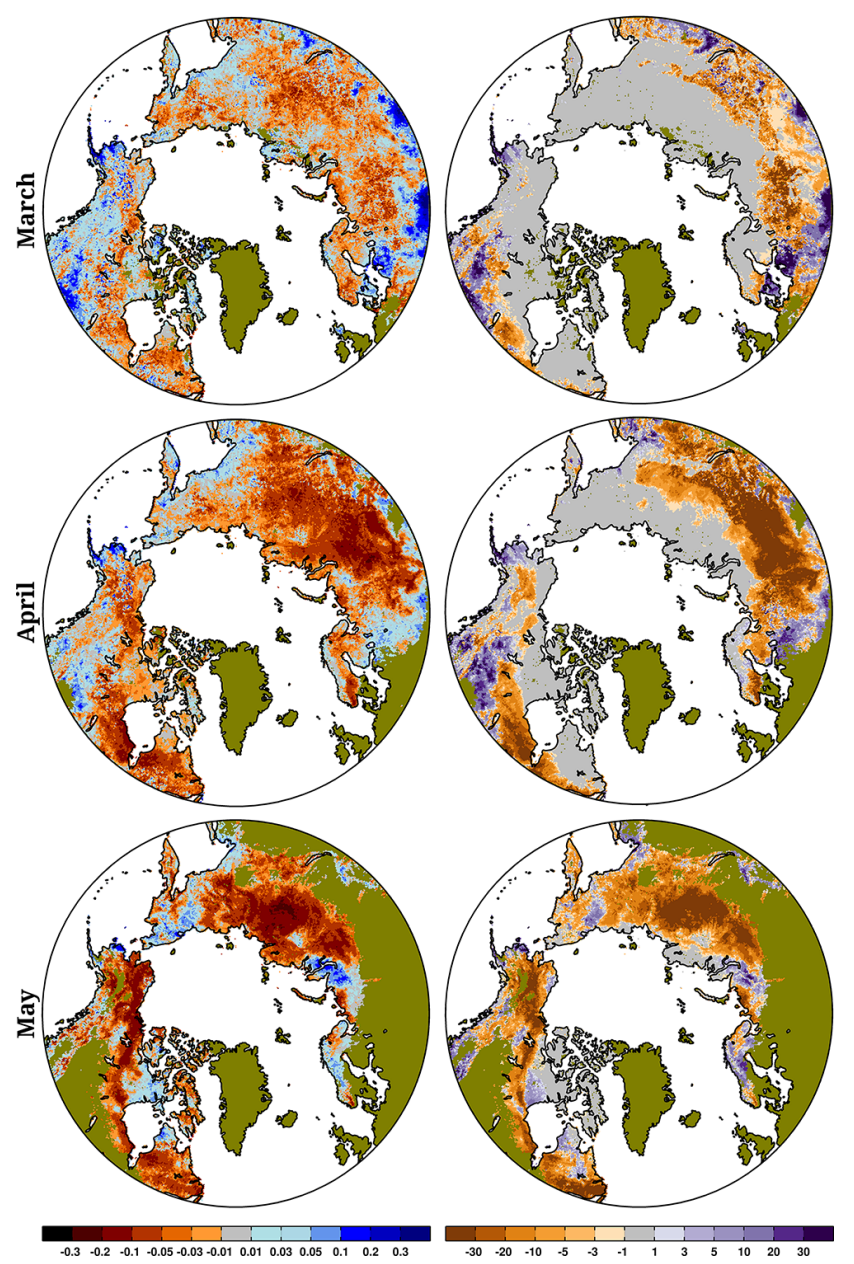

Figure 2. Average albedo (left panel) and SCF (right panel) changes during the years 2000-2012, determined as described in the text. Snow-free area, Greenland and Iceland are shown in green and are not considered in this study.

these two parameters trace each other well with extremes in the same years, indicating a strong connection. The variation of mean albedo with mean $\mathrm{SCF}$ in the $\mathrm{NH}_{50}$ study area (Fig. 4b) demonstrates the linear relationship between these two parameters. Correlation coefficients $R$ vary from 0.75 in March, 0.87 in April to 0.96 in May. Corresponding linear fit equations are shown on Fig. 4b. Thus SCF can explain 56\% of variation of the albedo in March, $76 \%$ in April and $92 \%$ in May.

However, in March and April in regions such as eastern Siberia, Fennoscandia, the northern part of North America or the Labrador Peninsula, and in May for the Taymyr Peninsula and the Canadian Archipelago, no significant SCF changes (less than $1 \% 12 \mathrm{yr}^{-1}$ ) are observed, but the albedo did change. This implies that factors other than SCF affect surface albedo. These other factors have a large impact: in conditions of unchanged snow cover extent, albedo changes by up to $\pm 0.212 \mathrm{yr}^{-1}$. To study effects of other parame- 


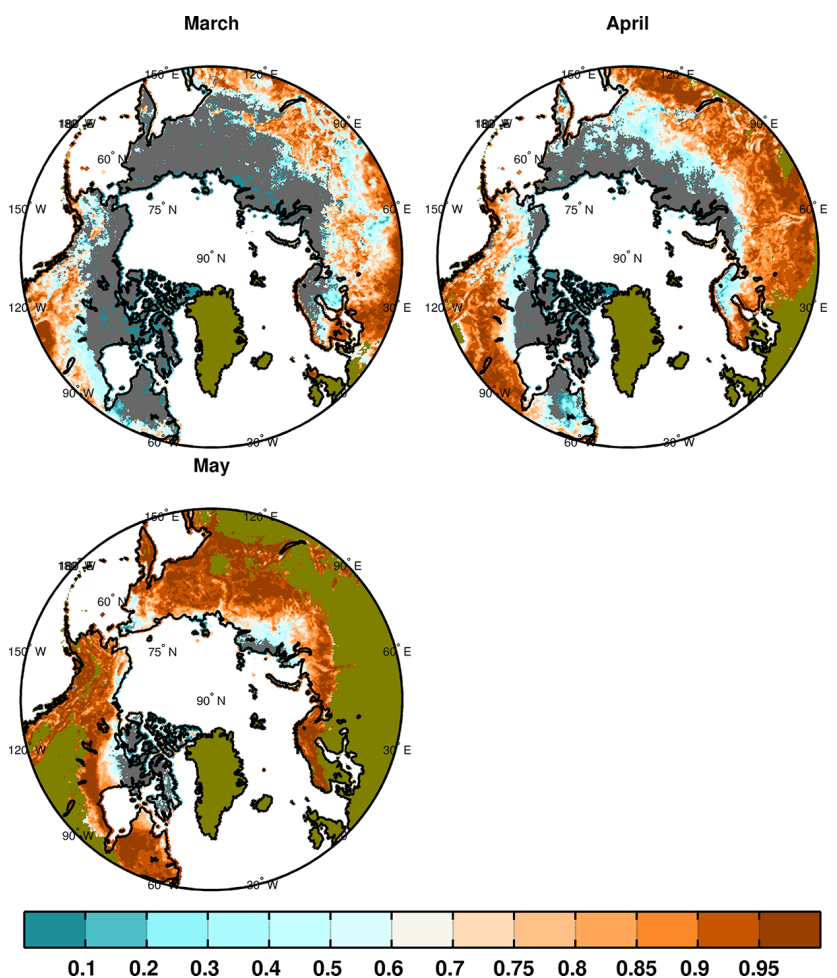

Figure 3. Albedo-SCF correlation coefficient maps. Gray color indicates areas where SCF is $100 \%$ throughout the study period: $R$ could not be calculated.

ters that potentially could cause the observed changes, further analysis was conducted over fully snow-covered pixels, i.e., pixels with $100 \%$ SCF.

\subsection{Regional study}

Scatter plots of regionally averaged values of albedo versus air temperature, precipitation amount, number of precipitating days and EVI for each of the 3 months are shown in Fig. 5. Corresponding Spearman correlation coefficients are listed in Table 1, and coefficients with a $p$ value $\leq 0.05$ are shown in bold. Below we discuss the effects of different parameters on the $100 \%$ snow-covered land surface albedo in separate subsections.

\subsubsection{Air temperature}

Regional averages show that albedo is negatively correlated with regionally averaged monthly mean air temperature when this parameter exceeds a threshold value of about $-15^{\circ} \mathrm{C}$ (Fig. 5, top line). Being the warmest from the study regions, Scandinavia already exhibits this relation in March, although the correlation is weak $(R=-0.49$, $p$ value $>0.05)$. Siberia and Labrador show this pattern in April with $R=-0.56$ and -0.88 , respectively. In May the correlation coefficient for the northern regions of Taymyr is -0.8 and for the Arctic Archipelago $R=-0.73$. For av-
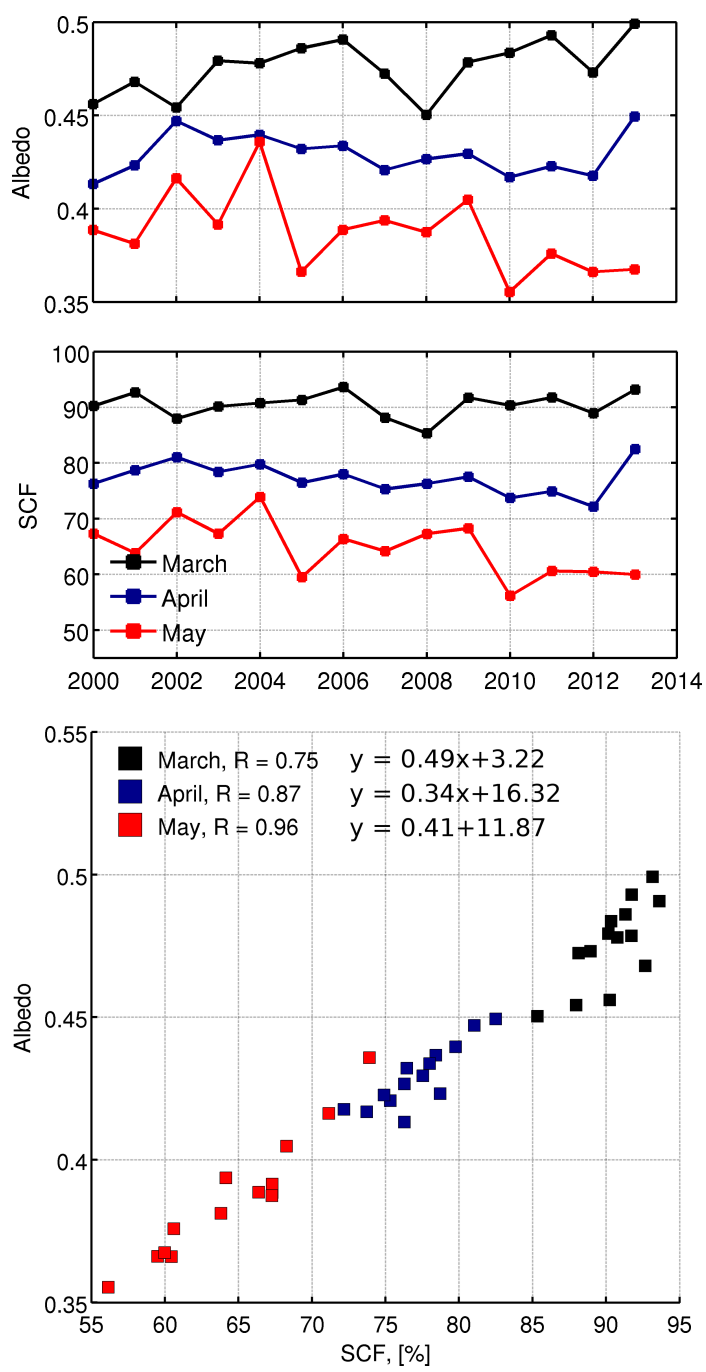

Figure 4. Time series (top panel) and scatter plot (bottom panel) of mean $\mathrm{NH}_{50}$ domain albedo and SCF for the years 2000-2013.

erage monthly temperatures in a region colder than $-15^{\circ} \mathrm{C}$, there is no or a very weak correlation between albedo and temperature.

\subsubsection{Precipitation amount and wet days}

Scatter plots of snow-covered land surface albedo versus the amount of precipitation (in $\mathrm{mm}$ ) are presented in Fig. 5 on the second row, and on the third row, scatter plots of albedo versus the number of days with precipitation are shown. In March no significant correlation is observed for any of the studied areas. The possible reason for this might be that areas that are too large are chosen for averaging, and effects of precipitation variations inside regions are averaged out. In April the precipitation amount in Canada correlates negatively with albedo $(R=-0.62, p$ value $<0.05)$. For the Arctic Archipelago $(R=0.7)$ and Taymyr $(R=0.65)$, the number of wet days and albedo are positively correlated with cor- 

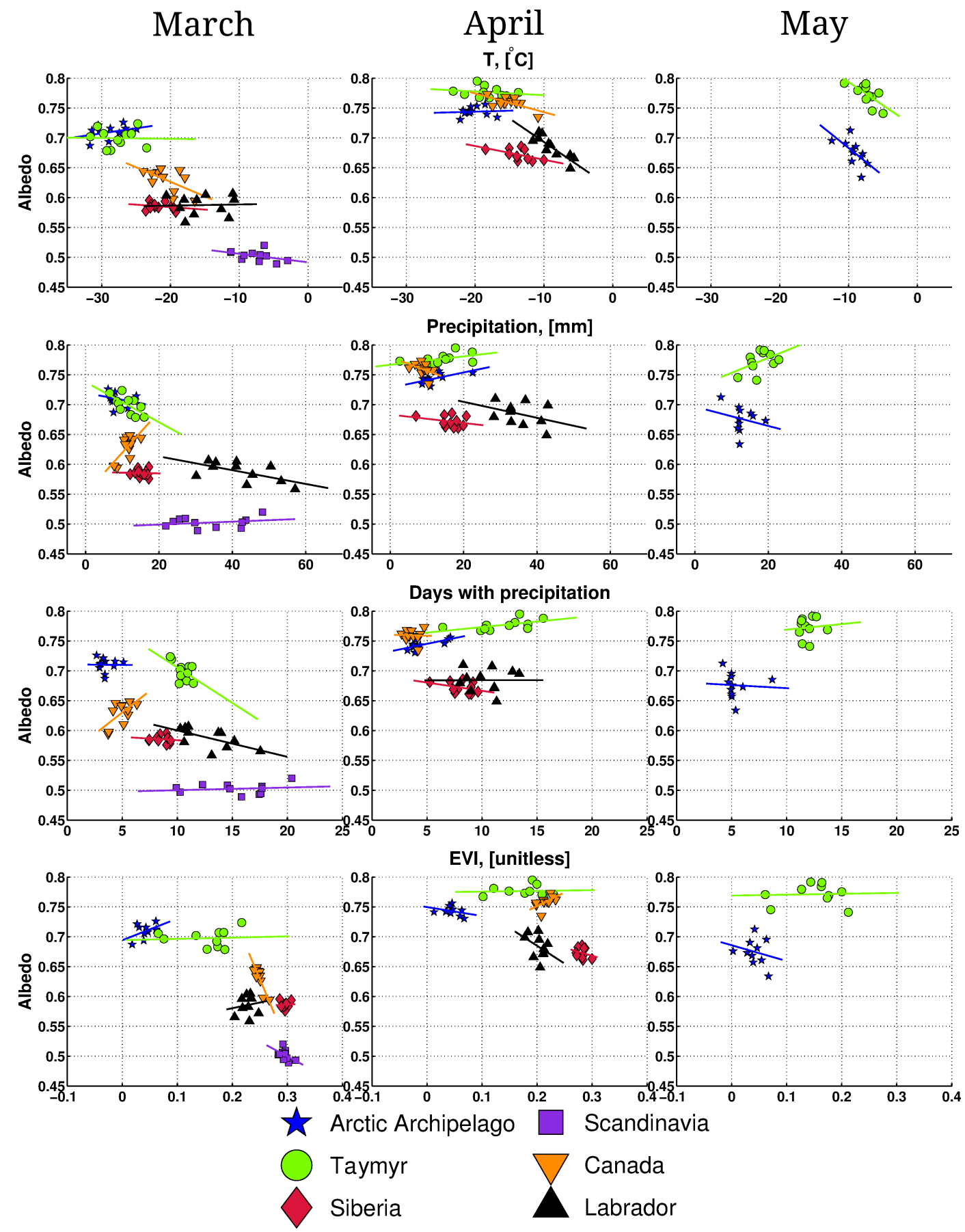

Figure 5. Snow-covered land area albedo versus mean regional air temperature (top panels), precipitation amount (second row panels), number of precipitating days (third row panels) and EVI (bottom panels). Straight lines show linear fits to the data. Corresponding Spearman correlation coefficients are listed in Table 1.

relation coefficients of 0.7 and 0.65 , respectively; $p$ values for both regions are less than 0.05. In May no significant correlations were found.

\subsubsection{EVI}

Scatter plots of snow-covered land surface albedo versus EVI are presented in Fig. 5 on the fourth row. Canada is the only region for which significant correlations between EVI and albedo are observed, with $R=-0.81$ in March and 0.79 in 
Table 1. Spearman correlation coefficients corresponding to the values presented in Fig. 5. Prec. represents precipitation; temp. represents temperature; EVI represents the Enhanced Vegetation Index. Correlation coefficients with corresponding $p$ value $<0.05$ are shown in bold.

\begin{tabular}{|c|c|c|c|c|c|c|c|c|c|c|c|c|}
\hline & \multicolumn{4}{|c|}{ March } & \multicolumn{4}{|c|}{ April } & \multicolumn{4}{|c|}{ May } \\
\hline & Temp. & Prec. & $\begin{array}{l}\text { Wet } \\
\text { days }\end{array}$ & EVI & Temp. & Prec. & $\begin{array}{l}\text { Wet } \\
\text { days }\end{array}$ & EVI & Temp. & Prec. & $\begin{array}{r}\text { Wet } \\
\text { days }\end{array}$ & EVI \\
\hline Arctic Arch. & 0.24 & -0.4 & -0.03 & 0.22 & 0.16 & 0.57 & 0.7 & -0.18 & -0.73 & -0.15 & -0.42 & -0.15 \\
\hline Taymyr & 0.0 & -0.57 & -0.28 & 0.19 & -0.28 & 0.53 & 0.65 & -0.14 & -0.8 & 0.35 & 0.12 & -0.26 \\
\hline Siberia & -0.26 & -0.14 & -0.28 & 0.22 & -0.56 & -0.32 & -0.39 & -0.32 & - & - & - & - \\
\hline Scandinavia & -0.49 & 0.11 & 0.06 & -0.49 & - & - & - & - & - & - & - & - \\
\hline Canada & -0.44 & 0.52 & 0.55 & -0.81 & -0.26 & -0.62 & 0.01 & 0.79 & - & - & - & - \\
\hline Labrador & 0.08 & -0.49 & -0.52 & -0.22 & -0.88 & -0.21 & -0.07 & -0.38 & - & - & - & - \\
\hline
\end{tabular}

April. No significant correlation was found for any of the other regions at any time. Despite the fact that the strongest greening is observed over subarctic areas (Fig. S1 from Supplement), on a regional scale we could not find a connection between EVI changes and albedo.

\subsection{Correlation maps}

Figure 6 shows the spatial distributions of the Spearman correlation coefficients of albedo with the four climate parameters considered in this study: temperature, precipitation, number of wet days and EVI (top to bottom panels in Fig. 6). Pixels with corresponding $p$ values greater than 0.1 were screened out from the maps.

\subsubsection{Temperature}

The previous results did not show a significant correlation between temperature and albedo in any of the considered regions in March. However, closer examination of the maps reveals negative correlations in the southern part of the study domain in North America, i.e., albedo decreases with increasing air temperature, and positive correlations in the northern part of this area (increase with increasing air temperature). This relation has been averaged out in a regional study. The mean temperature in the area with negative correlation is higher than $-15^{\circ} \mathrm{C}$ (Fig. S2). In areas with positive correlation mean monthly temperatures are colder than $-15^{\circ} \mathrm{C}$. In Eurasia the only region with monthly mean temperature above $-15^{\circ} \mathrm{C}$ is Scandinavia, where some areas exhibit the same relation. There is also a vast area of the Lena and Yana river basins and the Vilyuy Plateau, where the temperature-albedo correlation is negative and significant.

In North America the temperature and albedo in April are related in a similar way as in March. In the areas with mean monthly temperatures warmer than $-15^{\circ} \mathrm{C}$, correlations are negative and significant. In Eurasia albedo and temperature are negatively correlated over almost the whole area. The strongest correlations were found in the northern part of the West Siberian Plain: $R$ reaches -0.7 . Mean temperatures in the region are higher than $-15^{\circ} \mathrm{C}$.
In May temperatures are higher than $-15^{\circ} \mathrm{C}$ everywhere in the study area, which includes a small part of northern Canada and the Arctic Archipelago, and some areas of the Taymyr Peninsula. Correlation between albedo and temperature in May is strongly negative and significant for all studied territories.

\subsubsection{Precipitation}

In March the correlation maps of albedo and precipitation amount show very high variability, which is especially prominent in North America. Due to this fact, no conclusion can be reached as regards a possible connection between these variables in North America. However, several isolated regions with significant positive correlation can be distinguished in Eurasia, such as Chukotka Peninsula, Magadan area, a few isolated areas in eastern Siberia and the Gulf of Ob. In contrast, negative correlation is observed in the Taymyr Peninsula.

In April the correlations between albedo and precipitation are negative in study areas in North America - Nunavut and Labrador. In Eurasia the correlation coefficients show that there is a weaker connection between albedo and precipitation than in March. Nevertheless, two small regions stand out: Taymyr with positive correlations and the Ob delta with negative correlations. It is notable that the correlation sign in these areas in April is opposite to those in March.

In May a negative significant correlation is detected in Nunavut.

\subsubsection{Number of wet days}

The correlation maps for the albedo and the number of wet days show generally similar patterns as for the precipitation amount. In March, for Chukotka, Magadan, the Central Siberian Plateau and the Gulf of Ob, both positive and significant correlations are observed, and on the Taymyr Peninsula, only negative values occur. High variability is observed over North America, with the exception of Labrador with negative correlation, and, therefore, the results are generally inconclusive. 

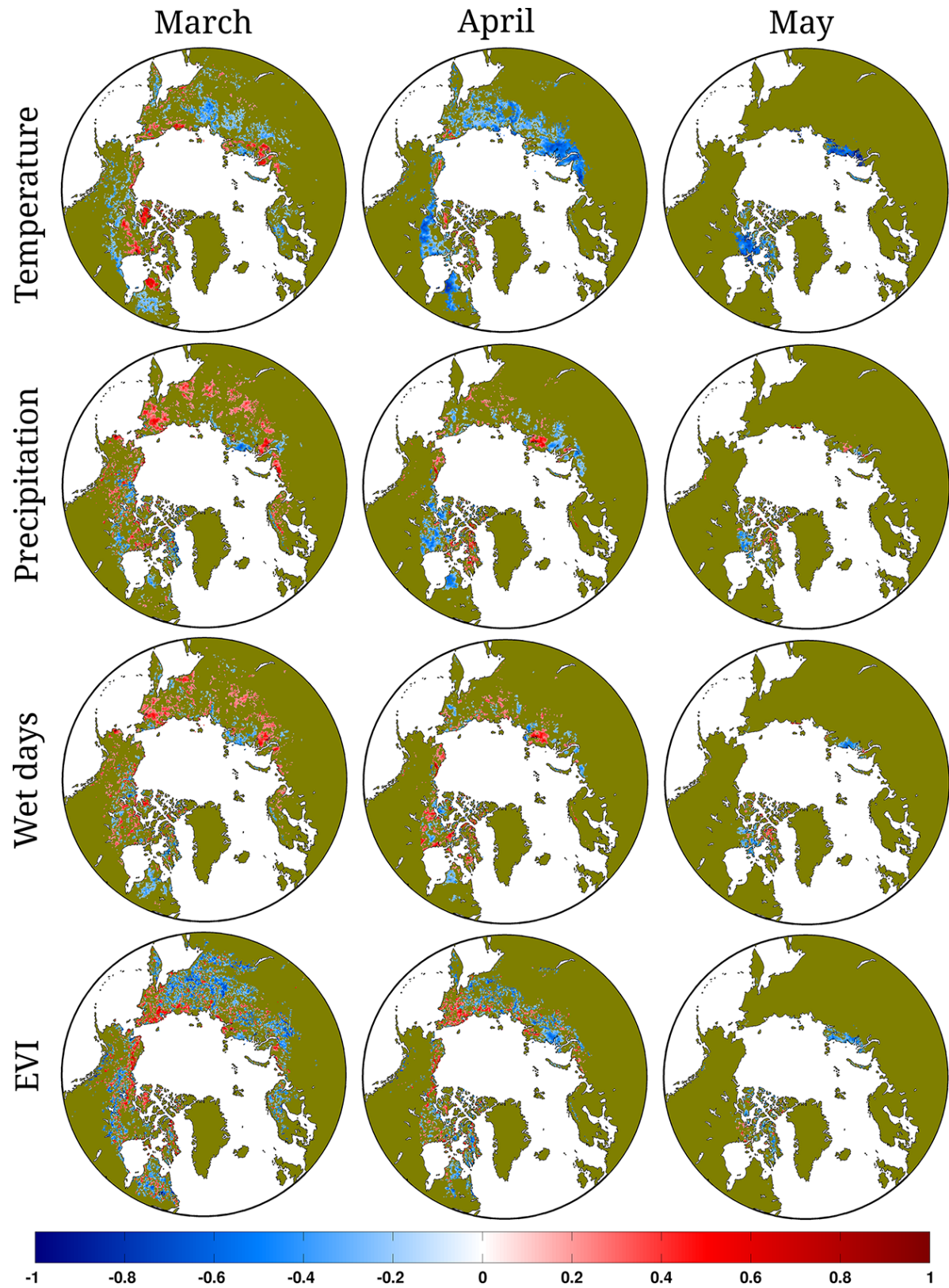

Figure 6. Spearman correlation coefficient map for temperature (top row panels), precipitation (second row panels), number of days with precipitation (third row panels) and EVI (bottom row panels) for March (left column panels), April (middle column panels) and May (right column panels). Only pixels with corresponding $p$ values greater than 0.1 are shown.

In April and May a strong variability occurs over almost all areas, excluding Taymyr where wet days and albedo are positively correlated in April.

\subsubsection{EVI}

Among all studied variables, the EVI correlation coefficient and $p$ value fields are the most variable. Nonetheless, in March and April, vast territories in Siberia and Far East show a significant correlation, which is predominantly positive in Chukotka and negative in the rest of eastern Siberia. Due to the strong variability of the albedo versus EVI correlation coefficient maps in North America, no conclusion on the effect of changes in greenness on the surface albedo can be reached for any of the months.

\section{Discussion}

Among all tested variables, the surface albedo is most strongly correlated with SCF during the spring season. Significant high positive correlation between albedo and SCF 
was observed over most of the territories of the $\mathrm{NH}_{50}$ domain where SCF changes were detected. This behavior can be explained by the large contrast in albedo between snowcovered and the open surface: the albedo of snow usually significantly exceeds that of the underlying surface.

For the rest of the study area, where SCF remained unperturbed, albedo has changed by up to \pm 0.2 units $12 \mathrm{yr}^{-1}$. To test which climate variables affected these changes, we chose air temperature, precipitation and vegetation as the most probable candidates that would affect surface albedo.

Air temperature affects surface albedo most in conditions of non-changing SCF during spring. The results presented in Sect. 4 suggest that there is a threshold of about $-15^{\circ} \mathrm{C}$, above which the temperature does have a significant effect on the surface albedo, while at lower temperatures there seems to be no effect. This finding is supported by the relations found between regionally averaged albedo and air temperatures and also by the Spearman correlation maps. Averaging to the monthly means, however, complicates interpretation of the results. A long averaging period may level possible temperature fluctuations and hence the effect of potentially occurring warmer periods during the month over which the data are averaged, which favor snow metamorphosis, cannot be observed. To address this limitation, an independent data set of finer temporal resolution was analyzed. Data, methods and results are described in the Supplement. We found that the temperature threshold value depends on the region and can depart from $-15^{\circ} \mathrm{C}$. Notably, the coldest region of the Arctic Archipelago is characterized by the lowest threshold value of $-15^{\circ} \mathrm{C}$, consistent with the one found in the current analysis.

The effect of precipitation on surface albedo would be an increase in albedo when it snows, resulting in a positive correlation. However, there is no clear pattern to confirm such an effect. The number of wet days and albedo correlated positively in April in two regions - Arctic Archipelago $(R=0.7)$ and Taymyr $(R=0.65)$; both regions are part of the tundra ecozone. However, in this month the precipitation amount and albedo show a significant negative correlation in Canada with $R=-0.62$. The correlation maps in Fig. 6a support this finding. The maps also show that in the Taymyr region the correlation coefficients change from positive in March to negative in April. Furthermore, a significant correlation is observed in March in several regions in Eurasia for both amount and frequency, which was not apparent in the regional study; averaging over a large domain might obscure possible relations by the cancellation of positive and negative effects when there is a strong spatial variability. In general, in North America the correlations are highly heterogeneously distributed which renders the interpretation difficult, especially as regards the relation between the number of precipitation days and albedo.

The effect of air temperature on snow albedo can be described by metamorphosis processes changes. The model experiment by Flanner and Zender (2006) shows that temper- ature affects snow-albedo evolution, such that snow albedo decreases more as temperature is higher. Hachikubo et al. (2014) examine the effect of temperatures on the rate at which a specific snow surface area (SSA), a parameter depending on the microstructure of the snowpack and related to the snow albedo, decreases in isothermal conditions. Their comparison of snow samples stored at temperatures of -47 and $-19^{\circ} \mathrm{C}$ shows that SSA decays faster at higher temperatures. In terms of albedo this means that it decreases faster at warmer temperatures, even if the temperature is relatively cold. However, the influence of the air temperature on snow albedo should be discussed together with that of precipitation because of its effect on the temperature gradient in the snowpack and, therefore, the metamorphosis regime. Taillandier et al. (2007) discusses possible feedbacks between snow metamorphism and snow albedo in a changing climate. Because snow crystals grow faster at higher temperatures, the albedo of a snow-covered surface will decrease in a warming climate, contributing to the positive feedback loop. However, there are other parameters, such as snow precipitation amount and frequency, and wind speed, which can alter this straightforward temperature-albedo dependency. If precipitation amount increases together with temperature, the net effect is such that grain size does not grow as fast as it would in warmer temperatures without precipitation regime change or snowpack thickness alterations. This way warming temperatures can produce negative feedback. If precipitation increases in isothermal conditions, the metamorphosis rate can decrease when a certain temperature gradient threshold in the snowpack is passed. Through this mechanism, the decrease of the snow albedo is slower. The present study is targeted to investigating changes in the snow-covered surface albedo on large spatial and temporal scales. The relatively large grid size of data and coarse averaging to monthly means could blend complicated connections between albedo, temperature and precipitation. For instance, an occasional rise of the temperatures, favoring snowpack thawing and subsequent refreezing, leads to the formation of the large amorphous ice crystals or melt-freeze crust on the snowpack surface (Colbeck, 1982) that is characterized by a decreased albedo (Albert and Perron, 2000). Decreasing albedo during snowmelt periods (Meinander et al., 2013) might have been obscured by averaging over long periods. The analysis presented in the Supplement studies the albedo-temperature relation using data with a finer temporal resolution. The results show that days that are warmer than average did not occur often. Moreover, even with a low number of warmer days, temperature threshold of $-15^{\circ} \mathrm{C}$ can be observed in some regions. Considering the above discussion, we cannot be conclusive which of the processes can give the best explanation of our findings.

The research presented above allowed us to identify some connection between EVI and albedo. The regional study shows that only in Canada a significant Spearman correlation is obtained in March, when $R$ is negative and thus albedo de- 
creases with EVI, and April when $R$ is positive and albedo increases with EVI. The obtained correlation maps, as in the case of precipitation variables, show a high spatial variability. Regardless of this, the results show an evident positive correlation in Chukotka and a negative correlation in large territories of the Far East and eastern Siberia in March and April. There might be several possible reasons behind these results due to various processes involved in the vegetationalbedo feedback. The effect of arctic shrub in the tundra on snow accumulation, melt rate and albedo is not clear and depends on canopy height, density and whether shrubs are subject to bending under the weight of the snowpack during winter (Pomeroy et al., 2006). For instance, snow tends to melt faster under tall shrubs, though snow accumulation is greater, resulting in a longer snowmelt period in comparison with sparse tundra. At the same time, exposure of darker vegetation material causes a reduction of the surface albedo. Generally, the dynamics of the albedo of tundra during the spring depends on the dominant vegetation type (Loranty et al., 2011) and, therefore, detailed tundra vegetation discrimination would be necessary for better understanding the effect of vegetation on springtime albedo on a large scale. Expansion of vegetation or change in vegetation type also alters wind fields. Wind speed decreases under the canopy, preventing densification of the snow from wind impact, which in turn slows metamorphism and, consequently, the decrease of albedo. On the other hand, the time of the thaw period is delayed when the forest fraction increases (e.g., Link and Marks, 1999; Koivusalo and Kokkonen, 2002). Furthermore, denser canopies in forest can intercept more snow, which can increase the albedo. For example, Kuusinen et al. (2012) found that in the boreal Scots pine forests the forest albedo can increase by as much as $20 \%$. At the same time, snow captured by the canopy can sublimate; thus, this portion of snow does not reach the forest surface, resulting in a shallower snowpack (Strasser et al., 2011).

In this study, changes in the wind field were not considered. As mentioned above, wind can increase snow density. In that case the temperature gradient in the snowpack is reduced, and it slows metamorphism processes and, subsequently, snow albedo decrease (Flanner and Zender, 2006). However, if strong wind redistributes old snow with low SSA, fragmentation and sublimation of snow crystals during a high wind episode will result in higher SSA and snow albedo (Domine et al., 2009). Another factor not discussed in this work is the sedimentation of impurities on the snow, such as light-absorbing aerosols. The presence of such a kind of impurities affects the albedo in the visible part of the spectrum (Meinander et al., 2013); however, it has no influence on the albedo at wavelengths beyond $0.9 \mu \mathrm{m}$ (Warren and Wiscombe, 1980). In a warming climate, when the snowpack consists of larger grain sizes, black carbon sedimented on the snow surface can amplify radiative perturbation caused by these impurities (Hadley and Kirchstetter, 2011). Moreover, there is evidence that the presence of absorbing aerosols on the snowpack surface can reduce the snow density (Meinander et al., 2014), which in turn influences the albedo decline rate in aging snow (Flanner and Zender, 2006).

\section{Conclusions}

Spring surface albedo has undergone significant changes during recent years. We studied the effects of snow cover, air temperature, precipitation amount and frequency and vegetation greenness on surface albedo. There is clear evidence of a strong connection between albedo and changes in snow cover fraction in the study domain due to the large difference in reflectance of snow-covered and snow-free surfaces. We also found that in the territories where the snow cover fraction did not change, the albedo changed nonetheless by \pm 0.2 units $12 \mathrm{yr}^{-1}$. Our results suggest that air temperature is one of the possible reasons for this albedo change when it exceeds a value between -15 and $-10^{\circ} \mathrm{C}$, depending on the region, above which the albedo and the temperature are negatively correlated. Furthermore, precipitation and vegetation are of importance in some areas, such as Chukotka, Taymyr, and eastern Siberia. The high spatial variability of the obtained correlation fields illustrates the complexity of the feedbacks and mechanisms in the climate system at high latitudes. It is clear that more detailed information is needed to identify and quantify relations between precipitation, vegetation and albedo in a changing climate with confidence.

\section{The Supplement related to this article is available online at doi:10.5194/tc-9-1879-2015-supplement.}

Acknowledgements. Financial support from the Nordic Center of Excellence CRAICC and the Academy of Finland Center of Excellence program (grants no. 1118615 and 272041) is gratefully acknowledged. The MCD43C3 and MOD13C2 data products are courtesy of the online Data Pool at the NASA Land Processes Distributed Active Archive Center (LP DAAC), USGS/Earth Resources Observation and Science (EROS) Center, Sioux Falls, South Dakota (https://lpdaac.usgs.gov/data_access). We also thank Jaakko Ikonen and Boyan Tabakov for the data analysis advice and technical assistance.

Edited by: S. M. Noe

\section{References}

Albert, M. R. and Perron, F. E.: Ice layer and surface crust permeability in a seasonal snow pack, Hydrol. Process., 14, 3207-3214, 2000.

Alton, P.: A simple retrieval of ground albedo and vegetation absorptance from MODIS satellite data for parameterisation of global Land-Surface Models, Agr. Forest Meteorol., 149, 1769$1775,2009$. 
Aoki, T., Hachikubo, A., and Hori, M.: Effects of snow physical parameters on shortwave broadband albedos, J. Geophys. Res.Atmos., 108, 4616, doi:10.1029/2003JD003506, 2003.

Aoki, T., Motoyoshi, H., Kodama, Y., Yasunari, T. J., Sugiura, K., and Kobayashi, H.: Atmospheric Aerosol Deposition on Snow Surfaces and Its Effect on Albedo, Scient. Onl. Lett. Atmos. Meteorol. Soc. Jpn., 2, 13-16, 2006.

Baldocchi, D., Kelliher, F. M., Black, T. A., and Jarvis, P.: Climate and vegetation controls on boreal zone energy exchange, Global Change Biol., 6, 69-83, 2000.

Barichivich, J., Briffa, K. R., Myneni, R. B., Osborn, T. J., Melvin, T. M., Ciais, P., Piao, S., and Tucker, C.: Large-scale variations in the vegetation growing season and annual cycle of atmospheric $\mathrm{CO}_{2}$ at high northern latitudes from 1950 to 2011, Global Change Biol., 19, 3167-3183, 2013.

Bender, F. A. M., Rodhe, H., Charlson, R. J., Ekman, A. M. L., and Loeb, N.: 22 views of the global albedo - comparison between 20 GCMs and two satellites, Tellus A, 58, 320-330, 2006.

Best, M. J., Pryor, M., Clark, D. B., Rooney, G. G., Essery, R .L. H., Ménard, C. B., Edwards, J. M., Hendry, M. A., Porson, A., Gedney, N., Mercado, L. M., Sitch, S., Blyth, E., Boucher, O., Cox, P. M., Grimmond, C. S. B., and Harding, R. J.: The Joint UK Land Environment Simulator (JULES), model description Part 1: Energy and water fluxes, Geosci. Model Dev., 4, 677-699, doi:10.5194/gmd-4-677-2011, 2011.

Betts, A. K. and Ball, J. H.: Albedo over the boreal forest, J. Geophys. Res., 102, 28901-928909, 1997.

Bonan, G. B.: Forests and Climate Change: Forcings, Feedbacks, and the Climate Benefits of Forests, Science, 320, 1444-1449, 2008.

Brodzik, M. J. and Knowles, K.: EASE-Grid: a versatile set of equal-area projections and grids, in: Discrete Global Grids, edited by: Goodchild, M. and Kimerling, A. J., National Center for Geographic Information \& Analysis, Santa Barbara, CA, USA, http://www.ncgia.ucsb.edu/globalgrids-book/ ease_grid/ (last access: 23 September 2015), 2002.

Brown, R. D. and Robinson, D. A.: Northern Hemisphere spring snow cover variability and change over 1922-2010 including an assessment of uncertainty, The Cryosphere, 5, 219-229, doi:10.5194/tc-5-219-2011, 2011.

Carlson, T. N. and Ripley, D. A.: On the relation between NDVI, fractional vegetation cover, and leaf area index, Remote Sens. Environ., 62, 241-252, 1997.

Chapin III, F. S., Sturm, M., Serreze, M.C., McFadden J. P., Key, J. R., Lloyd, A. H., McGuire, A. D., Rupp, T. S., Lynch, A. H., Schimel, J. P., Beringer, J., Chapman, W. L., Epstein, H. E., Euskirchen, E. S., Hinzman, L. D., Jia, G., Ping, C.-L., Tape, K. D., Thompson, C. D. C., Walker, D. A., and Welker, J. M.: Role of Land-Surface Changes in Arctic Summer Warming, Science, 210, 657-660, 2005.

Colbeck, S. C.: An overview of seasonal snow metamorphism, Rev. Geophys., 20, 45-61, 1982.

Collins, W. D., Rasch, P. J., Boville, B. A., Hack, J. J., McCaa, J. R., Williamson, D. L., Kiehl, J. T., Briegleb, B., Bitz, C., Lin, S.-J., Zhang, M., and Dai, Y.: Description of the NCAR Community Atmosphere (CAM 3.0), Tech. Rep. NCAR TN-464+STR, National Center for Atmospheric Research, Boulder, CO, p. 214, 2004.
Davidson, A. and Wang, S.: The effects of sampling resolution on the surface albedos of dominant land cover types in the North American boreal region, Remote Sens. Environ., 93, 211-224, 2004.

Domine, F., Salvatori, R., Legagneux, L., Salzano, R., Fily, M., and Casacchia, R.: Correlation between the specific surface area and the short wave infrared (SWIR) reflectance of snow, Cold Reg. Sci. Technol., 46, 60-68, 2006.

Domine, F., Taillandier, A.-S., Cabanes, A., Douglas, T. A., and Sturm, M.: Three examples where the specific surface area of snow increased over time, The Cryosphere, 3, 31-39, doi:10.5194/tc-3-31-2009, 2009.

Dutrieux, L. P., Bartholomeus, H., Herold, M., and Verbesselt, J.: Relationships between declining summer sea ice, increasing temperatures and changing vegetation in the Siberian Arctic tundra from MODIS time series (2000-11), Environ. Res. Lett., 7, 44028, doi:10.1088/1748-9326/7/4/044028, 2012.

Flanner, M. G. and Zender, C. S.: Linking snowpack microphysics and albedo evolution, J. Geophys. Res.-Atmos., 111, D12208, doi:10.1029/2005JD006834, 2006.

Groisman, P. Y., Karl, T. R., and Knight, R. W.: Observed Impact of Snow Cover on the Heat Balance and the Rise of Continental Spring Temperatures, Science, 263, 198-200 1994.

Hachikubo, A., Yamaguchi, S., Arakawa, H., Tanikawa, T., Hori, M., Sugiura, K., Matoba, S., Niwano, M., Kuchiki, K., and Aoki, T.: Effects of temperature and grain type on time variation of snow specific surface area, Bull. Glaciol. Res., 32, 47-53, doi:10.5331/bgr.32.47, 2014.

Hadley, O. L. and Kirchstetter, T. W.: Black-carbon reduction of snow albedo, Nat. Clim. Change, 2, 437-440, 2012.

Hagemann, S., Loew, A., and Andersson, A.: Combined evaluation of MPI-ESM land surface water and energy fluxes, J. Adv. Model. Earth Syst., 5, 259-286, 2013.

Hall, D. K. and Riggs, G. A.: Accuracy assessment of the MODIS snow products, Hydrol. Process., 21, 1534-1547, 2007.

Hall, D. K., Riggs, G. A., Salomonson, V. V., DiGirolamo, N. E., and Bayr, K. J.: MODIS snow-cover products, Remote Sens. Environ., 83, 181-194, 2002.

Hansen, J. and Nazarenko, L.: Soot climate forcing via snow and ice albedos, P. Natl. Acad. Sci. USA, 101, 423-428, 2004.

He, T., Liang, S., and Song, D.-X.: Analysis of global land surface albedo climatology and spatial-temporal variation during 19812010 from multiple satellite products, J. Geophys. Res.-Atmos., 119, 10281-10298, doi:10.1002/2014JD021667, 2014.

Huete, A., Justice, C. O., and van Leeuwen, W.: MODIS Vegetation Index (MOD 13) Algorithm Theoretical Basis Document Version 3, NASA Goddard Space Flight Center, Greenbelt, Maryland, USA, 1999.

Huete, A., Didan, K., Miura, T., Rodriguez, E. P., Gao, X., and Ferreira, L. G.: Overview of the radiometric and biophysical performance of the MODIS vegetation indices, Remote Sens. Environ., 83, 195-213, 2002.

Huete, A., Didan, K., van Leeuwen, W., Miura, T., and Glenn, E.: MODIS Vegetation Indices, in: Land Remote Sensing and Global Environmental Change, edited by: Ramachandran, B., Justice, C. O., and Abrams, M. J., Remote Sensing and Digital Image Processing, Springer, New York, 2011. 
Idso, S. B., Jackson, R. D., Reginato, R. J., Kimball, B. A., and Nakayama, F. S.: The Dependence of Bare Soil Albedo on Soil Water Content, J. Appl. Meteorol., 14, 109-113, 1975.

IPCC: Climate Change 2013: The Physical Science Basis, in: Contribution of Working Group I to the Fifth Assessment Report of the Intergovernmental Panel on Climate Change, edited by: Stocker, T. F., Qin, D., Plattner, G.-K., Tignor, M., Allen, S. K., Boschung, J., Nauels, A., Xia, Y., Bex, V., and Midgley, P. M., Cambridge University Press, Cambridge, UK and New York, NY, USA, 1535 pp., 2013.

Jones, P. and Harris, I.: CRU TS3.21: Climatic Research Unit (CRU) Time-Series (TS) Version 3.21 of High Resolution Gridded Data of Month-by-month Variation in Climate (Jan.1901-Dec.2012), University of East Anglia Climatic Research Unit (CRU), NCAS British Atmospheric Data Centre, doi:10.5285/D0E1585D-3417-485F-87AE-4FCECF10A992, 24 September 2013.

Klein, A. G., Hall, D. K., and Riggs, G. A.: Improving snow cover mapping in forests through the use of a canopy reflectance model, Hydrol. Process., 12, 1723-1744, 1998.

Knowles, N., Dettinger, M. D., and Cayan, D. R.: Trends in snowfall versus rainfall in the western United States, J. Climate, 19, 45454559, 2006.

Koivusalo, H. and Kokkonen, T.: Snow processes in a forest clearing and in a coniferous forest, J. Hydrol., 262, 145-164, 2002.

Krasting, J. P., Broccoli, A. J., Dixon, K. W., and Lanzante, J. R.: Future changes in northern hemisphere snowfall, J. Climate, 26, 7813-7828, 2013.

Kuusinen, N., Kolari, P., Levula, J., Porcar-Castell, A., Stenberg, P., and Berninger, F.: Seasonal variation in boreal pine forest albedo and effects of canopy snow on forest reflectance, Agr. Forest Meteorol., 164, 53-60, 2012.

Link, T. E. and Marks, D.: Point simulation of seasonal snow cover dynamics beneath boreal forest canopies, J. Geophys. Res., 104, 27841-27857, 1999.

Liu, J., Schaaf, C., Strahler, A., Jiao, Z., Shuai, Y., Zhang, Q., Roman, M., Augustine, J. A., and Dutton, E. G.: Validation of Moderate Resolution Imaging Spectroradiometer (MODIS) albedo retrieval algorithm: Dependence of albedo on solar zenith angle, J. Geophys. Res.-Atmos., 114, D01106, doi:10.1029/2008JD009969, 2009.

Loranty, M. M., Goetz, S. J., and Beck, P. S. A.: Tundra vegetation effects on pan-Arctic albedo, Environ. Res. Lett., 6, 024014, doi:10.1088/1748-9326/6/2/024014, 2011.

Lucht, W., Schaaf, C. F., and Strahler, A. H.: An algorithm for the retrieval of albedo from space using semiempirical BRDF models, IEEE T. Geosci. Remote, 38, 977-998, 2000.

Lukeš, P., Rautiainen, M., Manninen, T., Stenberg, P., and Mõttus, M.: Geographical gradients in boreal forest albedo and structure in Finland, Remote Sens. Environ., 152, 526-535, 2014.

Marbouty, D.: An experimental study of temperature-gradient metamorphism, J. Glaciol., 26, 303-312, 1980.

Matthias, A. D., Post, D. F., Accioly, L., Fimbres, A., Sano, E. E., and Batchily, A. K.: Measurement of albedos for small areas of soil, Soil Science, 164, 293-301, doi:10.1097/00010694199905000-00001, 1999.

Meinander, O., Kazadzis, S., Arola, A., Riihelä, A., Räisänen, P., Kivi, R., Kontu, A., Kouznetsov, R., Sofiev, M., Svensson, J., Suokanerva, H., Aaltonen, V., Manninen, T., Roujean, J.-L., and
Hautecoeur, O.: Spectral albedo of seasonal snow during intensive melt period at Sodankylä, beyond the Arctic Circle, Atmos. Chem. Phys., 13, 3793-3810, doi:10.5194/acp-13-37932013, 2013.

Meinander, O., Kontu, A., Virkkula, A., Arola, A., Backman, L., Dagsson-Waldhauserová, P., Järvinen, O., Manninen, T., Svensson, J., de Leeuw, G., and Leppäranta, M.: Brief communication: Light-absorbing impurities can reduce the density of melting snow, The Cryosphere, 8, 991-995, doi:10.5194/tc-8-9912014, 2014.

Melloh, R. A., Hardy, J, P., Davis, R. E., and Robinson, P. B.: Spectral albedo/reflectance of littered forest snow during the melt season, Hydrol. Process., 15, 3409-3422, 2001.

Mitchell, T. D. and Jones, P. D.: An improved method of constructing a database of monthly climate observations and associated high-resolution grids, Int. J. Climatol., 25, 693-712, 2005.

Naito, A. T. and Cairns, D. M.: Patterns and processes of global shrub expansion, Prog. Phys. Geogr., 35, 423-442, 2011.

Nakamura, T., Abe, O., Hasegawaa, T., Tamuraa, R., and Ohtaa, T.: Spectral reflectance of snow with a known grain-size distribution in successive metamorphism, Cold Reg. Sci. Technol., 32, 1326, 2001.

NASA Land Processes Distributed Active Archive Center (LP DAAC): MCD43C3, USGS/Earth Resources Observation and Science (EROS) Center, Sioux Falls, South Dakota, 2006a.

NASA Land Processes Distributed Active Archive Center (LP DAAC): MOD13C2. USGS/Earth Resources Observation and Science (EROS) Center, Sioux Falls, South Dakota, 2006b.

Ormsby, J. P., Choudhury, B. J., and Owe, M.: Vegetation spatial variability and its effect on vegetation indices, Int. J. Remote Sens., 8, 1301-1306, 1987.

Peng, S., Piao, S., Ciais, P., Friedlingstein, P., Zhou, L., and Wang, T.: Change in snow phenology and its potential feedback to temperature in the Northern Hemisphere over the last three decades, Environ. Res. Lett., 8, 014008, doi:10.1088/17489326/8/1/014008, 2013.

Pomeroy, J. W., Bewley, D. S., Essery, R. L. H., Hedstrom, N. R., Link, T., Granger, R. J., Sicart, J. E., Ellis, C. R., and Janowicz, J. R.: Shrub tundra snowmelt, Hydrol. Process., 20, 923-941, 2006.

$\mathrm{Qu}, \mathrm{X}$. and Hall, A.: On the persistent spread in snow-albedo feedback, Clim. Dynam., 42, 69-81, 2014.

Roeckner, E., Bauml, G., Bonaventura, L., Brokopf, R., Esch, M., Giorgetta, M, Hagemann, S., Kirchner, I., Kornblueh, L., Manzini, E., Rhodin, A., Schlese, U., Schulzweida, U., and Tompkins, A.: The Atmospheric General Circulation Model ECHAM5: Part 1, Technical Report 349, Max Planck Institute for Meteorology, http://www.mpimet.mpg.de/fileadmin/models/ echam/mpi_report_349.pdf (last access: 23 September 2015), 2003.

Roesch, A., Gilgen, H., Wild, M., and Ohmura, A.: Assessment of GCM simulated snow albedo using direct observations, Clim. Dynam., 15, 405-418, 1999.

Salomon, J. G., Schaaf, C. B., Strahler, A. H., Feng, G., and Yufang, J.: Validation of the MODIS bidirectional reflectance distribution function and albedo retrievals using combined observations from the aqua and terra platforms, IEEE T. Geosci. Remote, 44, 15551565, 2006. 
Salomonson V. V. and Appel, I.: Estimating the fractional snow covering using the normalized difference snow index, Remote Sens. Environ., 89, 351-360, 2004.

Schaaf, C. B., Gao, F., Strahler, A. H., Lucht, W., Li, X., Tsang, T., Strugnell, N. C., Zhang, X., Jin, Y., Muller, J.-P., Lewis, P., Barnsley, M., Hobson, P., Disney, M., Roberts, G., Dunderdale, M., Doll, C., d'Entremont, R., Hu, B., Liang, S., and Privette, J. L.: First operational BRDF, albedo and nadir reflectance products from MODIS, Remote Sens. Environ., 83, 135-148, 2002.

Schaaf, C. B., Liu, J., Gao, F., and Strahler, A. H.: Aqua and Terra MODIS Albedo and Reflectance Anisotropy Products, in: Land Remote Sensing and Global Environmental Change, Remote Sensing and Digital Image Processing, Springer, New York, 2011.

Screen, J. A.: Arctic amplification decreases temperature variance in northern mid- to high-latitudes, Nat. Clim. Change, 4, 577$582,2014$.

Song, J.: Phenological influences on the albedo of prairie grassland and crop fields, Int. J. Biometeorol., 42, 153-157, 1999.

Strasser, U., Warscher, M., and Liston, G. E.: Modeling SnowCanopy Processes on an Idealized Mountain, J. Hydrometeorol., 12, 663-677, 2011.

Stroeve, J., Box, J. E., Gao, F., Liang, S., Nolin, A., and Schaaf, C.: Accuracy assessment of the MODIS 16-day albedo product for snow: comparisons with Greenland in situ measurements, Remote Sens. Environ., 94, 46-60, 2005.

Sturm, M., Douglas, T., Racine, C., and Liston, G.: Changing snow and shrub conditions affect albedo with global implications, J. Geophys. Res.-Biogeo., 110, G01004, doi:10.1029/2005JG000013, 2005.

Taillandier, A.-S., Domine, F., Simpson, W. R., Sturm, M., and Douglas, T. A.: Rate of decrease of the specific surface area of dry snow: Isothermal and temperature gradient conditions, J. Geophys. Res., 112, F03003, doi:10.1029/2006JF000514, 2007.
Wang, S., Trishchenko, A. P., Khlopenkov, K. V., and Davidson, A.: Comparison of International Panel on Climate Change Fourth Assessment Report climate model simulations of surface albedo with satellite products over northern latitudes, J. Geophys. Res., 111, D21108, doi:10.1029/2005JD006728, 2006.

Wang, Z., Schaaf, C. B., Strahler, A. H., Chopping, M. J., Román, M. O., Shuai, Y., Woodcock, C. E., Hollinger, D. Y., and Fitzjarrald, D. R.: Evaluation of MODIS albedo product (MCD43A) over grassland, agriculture and forest surface types during dormant and snow-covered periods, Remote Sens. Environ., 140, 60-77, 2014.

Warren, S. G.: Optical properties of snow, Rev. Geophys. Space Phys., 20, 67-89, 1982.

Warren, S. G. and Wiscombe, W. J.: A model for the spectral albedo of snow, II: Snow containing atmospheric aerosols, J. Atmos. Sci., 37, 2734-2745, 1980 .

Winkler, R., Boon, S., Zimonick, B., and Baleshta, K.: Assessing the effects of post-pine beetle forest litter on snow albedo, Hydrol. Process., 24, 803-812, 2010.

Wiscombe, W. J. and Warren, S. G.: A Model for the Spectral Albedo of Snow, I: Pure Snow, J. Atmos. Sci., 37, 2712-2733, 1980.

Wuttke, S., Seckmeyer, G., and König-Langlo, G.: Measurements of spectral snow albedo at Neumayer, Antarctica, Ann. Geophys., 24, 7-21, doi:10.5194/angeo-24-7-2006, 2006.

Zhang, Q., Xiao, X., Braswell, B., Linder, E., Ollinger, S., Smith, M.-L., Jenkins, J. P., Baret, F., Richardson, A. D., Moore Iii, B., and Minocha, R.: Characterization of seasonal variation of forest canopy in a temperate deciduous broadleaf forest, using daily MODIS data, Remote Sens. Environ., 105, 189-203, 2006. 